\title{
Auditing Research Summaries
}

\author{
Philip Wallage
}

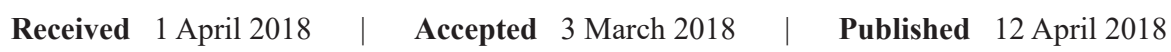

Hierbij presenteren wij weer een vijftal "Auditing Research Summaries" uit de database van de American Accounting Association (www.auditingresearchsummaries.org).

De eerste samenvatting betreft een interessant onderzoek naar de mogelijke gevolgen van persoonlijke relaties tussen leden van de audit commissie (AC) en de CEO van Amerikaanse genoteerde ondernemingen. Hiertoe is door Bruynseels and Cardinaels (2014) onderzocht of een dergelijke persoonlijke relatie invloed heeft op de kwaliteit van het toezicht. De aard van de persoonlijke relaties is in kaart gebracht aan de hand van zakelijke banden, overeenkomsten in gevolgde opleiding en aan de hand van banden als gevolg van overige niet-professionele activiteiten. Onder de laatstgenoemde categorie vallen zaken als lidmaatschap van service clubs, brancheverenigingen en dergelijke. Uit het onderzoek blijkt dat sociale banden tussen CEO en leden van het $A C$, gemeten aan de hand van de niet-professionele activiteiten, de kwaliteit van het toezicht (kwaliteit van de financiële rapportage en auditinspanningen) kunnen verminderen. Dit effect is echter niet gemeten voor professionele banden of voor banden die bestaan door de gevolgde opleiding.

De tweede samenvatting betreft een onderzoek van Brown et al. (2013) naar de "insurance hypothesis". Hiertoe is aan de hand van schikkingen rondom de zogenaamde "Tax Shelter Case" nagegaan of de vraag naar accountantscontrole kan worden verklaard vanuit een verzekeringsperspectief. Resultaten van een event studie impliceren dat klanten van KPMG in de Verenigde Staten significant negatieve "abnormal market returns" tonen tijdens negatieve publiciteit over een onderzoek van de Amerikaanse overheid naar de mogelijke verkoop van "tax shelter" producten aan klanten. Na een schikking met de overheid in 2005, ontstonden echter positieve "abnormal market returns". Hieruit concluderen de onderzoekers dat de effectenmarkt de accountant ziet als een verzekeraar. Als de accountant negatief in het nieuws is leidt dat tot een relatieve daling van de beurskoers van klanten.
In een paper van Franzel (2014), voormalig lid van de PCAOB, wordt de balans opgemaakt van 10 jaar Sarbanes Oxley Act. Franzel betoogt dat de integriteit van de information supply chain vereist dat alle participanten alert moeten zijn en adequaat moeten reageren op rode vlaggen. Het succes van het systeem wordt mede bepaald door wetenschappelijk onderzoek en onderwijs. Onderzoek zou zich onder meer moeten richten op de sterke en zwakke punten van het systeem maar ook op de invloed van wijzigingen in het systeem. Ook zou wetenschappelijk onderzoek moeten leiden tot aanbevelingen voor verbeteringen. Onderwijs kan bijdragen door het opleiden van toekomstige accountants die hun werk succesvol verrichten en zodoende beleggers en publiek beschermen en het vertrouwen in de beroepsuitoefening waarborgen.

Zijn accountants professioneel sceptisch vragen Feng and $\mathrm{Li}$ (2014) zich af. Om de vraag te beantwoorden hebben zij onderzocht hoe accountants de mogelijk geflatteerde resultaatverwachtingen van het management evalueren bij het beoordelen van de continuïteitsveronderstelling. Uit het onderzoek blijkt dat managementverwachtingen niet significant te zwaar worden meegewogen terwijl voorspellingen die twijfelachtig zijn, minder in de beoordeling worden betrokken. Dit impliceert dat accountants in het algemeen professioneel kritisch in dergelijke situaties.

De laatste samenvatting betreft een onderzoek van Dowling and Leech (2014) naar het gebruik van IT bij het beheersen van het controleproces zoals bij de introductie van een elektronisch dossier. Uit analyses van interne documentatie en interviews die bij een big 4-firm in Australië zijn gehouden, concluderen de onderzoekers dat in het geval deze systemen niet als dwangmatig worden ervaren er ruimte blijft voor het toepassen van persoonlijke kennis en vaardigheden. Daarnaast constateren zij onder meer dat reviewers vaker en tijdiger worden betrokken maar het risico bestaat dat door te veel 'bewaking' de effectiviteit van de professionele oordeelsvorming kan afnemen. 


\section{The audit committee: management watchdog or personal friend of the ceo?}

\section{Citation}

Bruynseels L, Cardinaels E (2014) The Audit Committee: Management Watchdog or Personal Friend of the CEO? The Accounting Review 89(1): 113-145.

\section{Practical implications}

The results of this study shed light on some unanticipated effects of the SOX mandate for "independent" audit committee members. While the growth in board and audit committee size that followed this mandate has led to improvements in audit committee expertise, CEOs might still appoint or maintain directors from their personal network of friends to build an audit committee that is sympathetic to their reporting choices.

Furthermore, the evidence is informative for shareholders, nomination and governance committees. Such parties might refrain from appointing a director in the audit committee who is too closely connected to the CEO. Additionally, it may be important to require more disclosure about the nature and type of social connections between audit committee members and the CEO.

\section{Purpose of the study}

To ensure that audit committees provide sufficient oversight over the auditing process and quality of financial reporting, legislators have imposed stricter requirements on the independence of audit committee members. Yet audit committee members who are fully independent according to SOX may still be connected to executives in many ways. They may serve together as directors on the board of another company, they may have worked together in the past as directors or employees, or they may have earned their MBA from the same university. Other connections may be formed outside professional or educational networks, such as those between committee members and executives attending the same business club, playing in the same golf club, working for the same charity, or other non-profit organization. This latter category of non-professional social ties is labeled as CEO-audit committee "friendship" ties.

The study predicts that connections may enable the CEO to appoint directors who are "friendly" to his or her reporting policies. This may have an impact on the audit committee's primary task to offer sufficient oversight over the reporting quality and audits of the financial statements.

This study explores:

- the extent and type of social ties observed between CEOs and audit-committee members

- whether such ties reduce the quality of audit committee monitoring.

\section{Design/Method/Approach}

This study uses a large dataset of U.S.-listed companies and focuses on the 2004 to 2008 post-SOX period. A distinction is made between fully independent audit committees and firms whose audit committee members have social ties with the CEO through either employment (e.g., shared current directorships or past employment/directorships), past education (e.g., graduating from the same school), or other non-professional activities (e.g. shared memberships in leisure clubs, charities, country clubs, industry associations etc). The authors assess the effect of these three types of CEO-audit committee social ties on various output variables that proxy for the oversight quality of the audit committee.

\section{Findings}

The sample of all firm-year observations shows that on average 17 percent of audit committee members share ties with their CEO, mainly through employment. On average in 39 percent of all firm-year observations, the audit committee includes at least one socially connected audit committee member.

The results show that:

- $\quad$ Friendship ties between CEOs and the audit committee may reduce the quality of the audit committee's oversight (proxied by financial reporting quality and levels of audit effort).

- Consistent with weaker oversight of the audit process, auditors are also less likely to issue going-concern opinions for firms in distress when friendship ties are present.

- Fewer internal control weaknesses are disclosed in the SOX 404 reports of firms with friendship ties. This presumably occurs because audit committees with such ties to the CEO offer the auditor less support when he or she disagrees with management over the type of internal control report to issue. Further analysis indeed suggests that firms with friendship ties are more likely to subsequently amend initially clean reports because of weak internal controls.

- Finally, professional and educational ties do not seem to produce negative effects on oversight quality.

\section{The insurance hypothesis: an examination of kpmg's audit clients around the investigation and settlement of the tax shelter case}

\section{Citation}

Brown DL, Shu SZ, Soo BS, Trompeter GM (2013) The Insurance Hypothesis: An Examination of KPMG's Audit Clients around the Investigation and Settlement of the Tax Shelter Case. Auditing: A Journal of Practice \& Theory $32(4)$ : 1-24. 


\section{Practical implications 2}

This paper makes an important contribution to the literature. Using a natural institutional setting, the authors find evidence of the insurance effect in a general sample of firms in the equity market. Understanding the role of the auditor insurance function and its association with client stock prices can help auditors to better understand the pricing of audit services and it can help lawmakers in assessing the costs and benefits of professional service litigation and of proposed future litigation reform legislation. The results aid investors in understanding one of the major economic roles of the audit function.

\section{Purpose of the study}

Although prior literature has suggested that independent audits provide an implicit form of insurance against investor losses (the "insurance hypothesis"), it has been challenging to isolate the "insurance" effect. In this paper, the authors use a unique setting to examine this effect. In 2002, KPMG was investigated by the U.S. Department of Justice in relation to tax shelters sold by the firm. From then until early 2005, several news reports suggested that KPMG would be indicted and suffer potentially the same fate as Arthur Andersen. However, in August of 2005 KPMG entered into a deferred prosecution agreement with the U.S. Department of Justice (DOJ), which ended widespread speculation of an impending federal indictment against the accounting firm. Because the investigation centered around tax services offered by the firm, the authors argue that the circumstances surrounding the investigation and settlement provide a natural setting to test the insurance value provided by auditors. Specifically, the authors examine the security price reactions of KPMG's audit clients to the news of their auditor's investigation by, and settlement with, the DOJ.

\section{Design/Method/Approach}

The authors use Compustat, CRSP and Audit Analytics to collect data. Depending on the event window, the sample varies from 920 for the settlement period to 920 to 1,012 for the investigation period. In addition to the event study, the authors also conduct a cross-sectional analysis. They use a smaller sample of 516 firms for this part of the analysis. The authors use data from the Summer 2002 to Summer 2005.

\section{Findings}

Focusing on the KPMG tax shelter investigation and settlement, the authors provide evidence consistent with an auditor insurance function being impounded in stock prices. Specifically, they find that KPMG client firms earn significantly negative abnormal returns during the periods when news reports indicated that it was subject to government prosecution over its role in marketing tax shelter products to its clients and earn positive abnormal returns following news of a settlement. They also examine whether these abnormal returns for KPMG clients are increasing for firms with a higher probability to utilize the insurance option, i.e., those subject to higher litigation risk and more financially distressed. As expected, results show that firms in financial distress and firms with high litigation risk experienced significantly higher abnormal returns.

\section{A decade after sarbanes-oxley: the need for ongoing vigilance, monitoring, and research}

\section{Citation}

Franzel JM (2014) A Decade after Sarbanes-Oxley: The Need for Ongoing Vigilance, Monitoring, and Research. Accounting Horizons 28(4): 917-930.

\section{Practical implications}

This paper provides views on many areas within the auditing profession that would benefit from further research and analysis, as well as opportunities for research that could be useful to the PCAOB as it considers current and future regulatory priorities.

\section{Keywords}

auditing quality, audit research, PCAOB, Public Company Accounting Oversight Board, Sarbanes-Oxley Act

\section{Purpose of the study}

After more than a decade since passage of the Sarbanes-Oxley Act and the creation of the Public Company Accounting Oversight Board (PCAOB), it is appropriate and necessary to ask questions about the present state of audit quality and evaluate the impact and effectiveness of PCAOB's oversight programs. Written from the viewpoint of a current PCAOB Board member and former Managing Director of the U.S. Government Accountability Office (GAO), this paper discusses the warning signs of serious auditing problems in the years preceding the Act, and the role that the GAO played in analyzing those risks and calling for greater oversight of the accounting profession's auditing public companies.

\section{Design/Method/Approach}

This paper provides the perspective of the author, a current PCAOB Board member, on the major issues debated during the development and passage of the Sarbanes-Oxley Act, specifically related to the oversight of the auditing profession and the creation of the PCAOB. 


\section{Findings}

The interrelated nature of corporate governance, accounting and financial reporting, the auditing of financial statements, and oversight of the accounting profession call on all stakeholders to work vigilantly to ensure the integrity of each aspect of this system. All participants need to be alert to warning signs and red flags and respond appropriately to maintain integrity and the public trust. Failure in any of these areas places a strain on the entire system and could threaten the capital markets and greater economic well-being. The successful functioning of this system also relies on academic researchers. The academic community plays a key role in this system of vigilance by conducting research and analysis, monitoring the strengths and weaknesses of the system at any given time, evaluating performance, across the financial system, studying the impact of specific actions, and generating recommendations for change. In addition, success of the entire system relies on educators preparing future members of the profession to successfully assume and carry out their responsibilities in maintaining integrity and public trust, while protecting investors and the public interest.

Are Auditors Professionally Skeptical? Evidence from...

\section{Are auditors professionally skeptical? Evidence from auditors' going-concern opinions and management earnings forecasts}

\section{Citation}

Feng M, Li C (2014) Are Auditors Professionally Skeptical? Evidence from Auditors' Going-Concern Opinions and Management Earnings Forecasts. Journal Of Accounting Research 52(5): 1061-1085.

\section{Practical implications}

The decision process concerning a firm's going-concern status is a crucial component of the overall audit. The authors provide new empirical evidence showing how auditors use potentially biased management forecasts in their going-concern decision process. Auditor professional skepticism is an important concept in audit practice as evidenced by its prominence throughout auditing standards. The authors show that auditors do not significantly overweight management forecasts on average, and even underweight management forecasts they perceive as being suspicious, indicating that auditors exercise professional skepticism when using management earnings forecasts. Thus, this paper is informative to regulators who are mainly concerned about auditors relying too heavily on what their clients tell them and failing to sufficiently test or challenge the forecasts, views, or representations of management.

\section{Keywords}

going-concern, management forecast, professional skepticism

\section{Purpose of the Study}

This paper investigates whether auditors exercise professional skepticism about management earnings forecasts when assessing a client firm's going-concern status. Professional skepticism is "an attitude that includes a questioning mind and a critical assessment of audit evidence". Regulators have long been concerned that auditors rely too much on what their clients tell them rather than applying professional skepticism. For example, a lack of professional skepticism is one primary cause of SEC actions against audit firms.

This paper sheds light on auditor professional skepticism due to the joint effect of three important factors.

- Prospective financial information provided by managers is an important input to auditors when they evaluate the client's going-concern status. Among this information, management earnings forecasts are particularly important because, if a financially distressed firm is expected to continue generating losses, the losses are likely to drain the firm's limited cash resources and increase the firm's likelihood of going bankrupt.

- Financially distressed firms tend to issue optimistically biased forecasts. Because the firms to which auditors consider issuing a going-concern opinion are generally financially distressed, professional skepticism could be especially important in this setting.

- Auditors could obtain management earnings forecasts through private communication with managers and/or public earnings forecasts.

\section{Design/Method/Approach}

The authors obtain data from financially distressed firms that have auditor reports available on Audit Analytics and are covered by the Compustat and First Call database for fiscal years 2000 through 2010. This results in final sample of 1,054 firm-year observations with 39 observations receiving going-concern opinions, and 33 filing for bankruptcy in the 12 months subsequent to the auditor opinion issuance date.

\section{Findings}

The authors find that, when management earnings forecasts are higher, the firms are less likely to receive 
going-concern opinions and to subsequently go bankrupt. Moreover, the coefficient on management forecasts in the going-concern model is not significantly different from the coefficient in the bankruptcy model. Hence, there is no significant evidence showing that auditors, on average, overweight management earnings forecasts and thus fail to apply professional skepticism when evaluating the firms' going-concern status.

The authors find that auditors' going concern decisions are not associated with management earnings forecasts with lower perceived credibility, but significantly and negatively associated with the other management earnings forecasts. In contrast, the likelihood of bankruptcy is significantly related to management earnings forecasts, regardless of auditor-perceived credibility. More importantly, the weight that auditors assign to management forecasts with low perceived credibility is significantly lower than the weight implied in the bankruptcy model. In other words, auditors' underweight management earnings forecasts that are issued by managers who previously missed their own forecasts and management forecasts that predict high earnings increases or high earnings.

\section{A big 4 firm's use of information technology to control the audit process: how an audit support system is changing auditor behavior}

\section{Citation}

Dowling C, Leech SA (2014) A Big 4 Firm's Use of Information Technology to Control the Audit Process: How an Audit Support System is Changing Auditor Behavior. Contemporary Accounting Research 31(1): 230-252.

\section{Practical implications}

The findings have important implications for audit firms that use information technology to facilitate engagement monitoring. The system improves audit review effectiveness and increases the frequency and timeliness of auditor interaction. The design of an audit support system can impact reviewer effectiveness. When used as a process control, audit support systems can have unintended consequences for auditor behavior and audit team interaction.

\section{Keywords}

process control, information technology, performance support systems

\section{Purpose of the study}

When audit support systems are used as a process control, audit firms are faced with the challenge of designing a system that balances features that ensure compliance with features that enable auditor autonomy and reduce overreliance on the system. An electronic workpaper system is an information technology that is an important component of an audit firm's risk management process. When used as a process control, the system promotes the effective and efficient delivery of audits.

To be an effective process control, a system needs to actively restrict auditors' independent behavior. This creates an operational risk because auditors could respond positively or negatively to a system. Auditors could respond negatively if they perceive the audit firm is using the system to coerce their effort and compliance with firm policies. Auditors who react negatively could disengage with their audit tasks because they perceive their tasks as routine or reject the system and work around it, thereby reducing the effectiveness of the system as a control. Conversely, auditors may respond positively to a structured system if they perceive that the structure clarifies their tasks and responsibilities. But, even if they respond positively, they may over rely on the system and not sufficiently assess the applicability of the system's recommendations for a specific client. The authors use internal documents and interviews with auditors at a Big 4 firm to analyze auditors' reactions to the firm's new audit support system.

\section{Design/Method/Approach}

The authors conducted 17 group interviews from three large Australian cities of the Big 4 firm. In total, the authors interviewed 51 auditors and one ex-regulator. The average audit experience of the participants was seven years (ranging from 2 to 37 years). Each group interview lasted approximately one hour (the range was from 50 to 90 minutes). The audit firm provided internal documents for analysis as well. The evidence was collected prior to the summer of 2014.

\section{Findings}

Although many of the system's features could have been used as a coercive control, this was not the case. Two primary factors explain their reaction:

1. Management's interventions during system deployment

2. How the system's design ensures compliance by providing audit teams with constrained choices in applying the system's recommendations.

These factors developed an auditor's sense of empowerment by leveraging their skills and knowledge. Empowerment became stronger following management interventions that encouraged audit teams to challenge the system's recommendations.

- The authors find that many of the system's features that enable monitoring and force reviewer involve- 
ment also increase the frequency and timeliness of preparer and reviewer interaction.

- System features that enable monitoring can inadvertently reduce preparer and reviewer independence, which may decrease the effectiveness of the audit review as an independent control mechanism.

- The auditors viewed the system positively and reported that it enables the effective delivery of audit engagements.

- Although the auditors reported that this was improving audit effectiveness and efficiency, they did not appear to have considered how this may reduce the independence of preparers' judgments. Increased interaction between preparers and reviewers increases the risk that preparers stylize their workpapers or align their judgments with reviewers' beliefs.

Overgenomen van www.auditingresearchsummaries.org, 2 april 2018 